\author{
Ronald J Burke ${ }^{1^{*}}$, Mustafa Koyuncu ${ }^{2}$ \\ and Lisa Fiksenbaum ${ }^{1}$ \\ ${ }^{1}$ Organizational Behaviour, York University, \\ Toronto Canada \\ ${ }^{2}$ Nevsehir University, Turkey \\ Dates: Received: 04 November, 2015; Accepted: \\ 04 February, 2016; Published: 06 February, 2016 \\ *Corresponding author: Ronald Burke, Professor, \\ Organizational Behaviour, York University, Toronto \\ Canada, E-mail: rburke@schulich.yorku.ca \\ www.peertechz.com
}

Research Article

\section{Flow, Work Satisfactions and Psychological Well-Being among Nurses in Turkish Hospitals}

\section{Introduction}

The fields of psychology and management have begun to devote more of their research attention to the positive side of individual wellbeing and the experiences of work and working as these contribute to well-being $[1,2]$, observed that the focus in psychology on negative states was greater than the focus on positive states by a factor of fourteen to one.

An emphasis on these negative experiences and outcomes is consistent with several decades of work in the field of psychology with its emphasis on pathology and illness [3], and the past forty years in the fields of organizational behavior and management with their emphasis on dissatisfaction, withdrawal behaviors and alienation in the workplace [4]. Recent developments in these fields, however, have fostered a different emphasis; an emphasis on human flourishing and individual strengths represented by the beginnings of positive psychology [5-7] and "what is right" in organizations represented by positive organizational scholarship [8] and positive organizational behavior [9]. Most of this work has been carried out in North America. Positive organizational scholarship (POS) focuses on positive outcomes such as flow, resilience, meaning, engagement, thriving and excellence -- the best of human and work conditions.

This research considers the experience of flow [10]. Flow can be experienced in a wide range of activities, work being only one of them Csikszentmihalyi [11], identified eight conditions associated with individual reports of experiencing flow clear goals, immediate feedback on progress, challenging but doable tasks, deep concentration, living in the present moment, feelings of control, being absorbed in the task so that one's sense of time changes, and submerging one's ego in the task. Unfortunately flow doesn't happen very often on one's job [12]. Most jobs do not provide the conditions associated with flow listed above.

\section{Flow}

The experience of flow has only recently been examined in traditional organizational jobs with much of the earlier work undertaken on athletes [13-19], trail hikers [20], aerobic dance exercisers [21], theater actors [22] and music students and music teachers [23-25] and in computer-assisted communication [26-28]. Studies in more traditional work settings have been reported by Bakker, Demerouti, Quinn, and Burke and Mattheisen [29-32].

Studies of flow in a variety of different settings have shown that the experience of flow was associated with higher levels of psychological well-being and performance [30,32-35]. One study [36], found that levels of flow were positively correlated with positive affect ad negatively correlated with negative affect in music students.

\section{Flow in the workplace}

Flow in the workplace has received some research attention. Burke and Matthiesen [32], using the Jackson and Marsh [15] measure of flow, considered correlates of flown a sample of Norwegian journalists. Journalists reporting more flow at work were older, had longer career and organizational tenure, worked in larger units and earned more money. Journalists indicating higher levels of flow also reported more work enjoyment, positive affect, and professional efficacy and lower levels of feeling driven to work because of inner pressures (less anxiety). Flow did not predict levels of absenteeism however.

Demerouti, using Bakker's [29,30]. WOLF measure of flow. Considered flow and job performance Data were collected from 113 respondents in a wide variety of occupations. She reported that motivating job characteristics predicted flow, and flow in turn, predicted both in-role and extra-role job performance as assessed by a colleague at work. But only among respondents high on conscientiousness. 
Bakker [29] reports on the development and validation of a measure of flow, the WOLF, having three components, intrinsic motivation and absorption and work enjoyment. These three components were found to be independent factors, and correlated with the Jackson and March [15] measure of flow. In addition, job characteristics predicted flow, and flow in turn was associated with ratings of job performance (e.g., in-role and extra-role job behaviors)

Quinn [31], collected both qualitative and quantitative data from a sample of scientists testing two models of flow. He did not find support for the Jackson and Marsh [15] model proposing that flow was a product of the nine features identified by Csikszentmihalyi [12]. Instead he found support for a model integrating the merging of awareness and application. He also observed that types of jobs held and type of tasks preformed influenced the experience of flow.

Finally, while not measuring flow directly, Eisen Berger, Jones, Stinglhamber, Shanouk and Randall [37], examined the relationship of employee's perceived skill and challenge at work, need for achievement, positive mood, intrinsic task interest, and extrarole performance. Data were collected from two large samples of employees working in a variety of jobs in the same eight workplaces. The found, similar to Demerouti [30], that among high achievement employees only, high skill and challenge were associated with positive mood, task interest, and performance.

These studies of flow in the workplace, along with the more general writing on flow [38-41], suggest the following conclusions. First, flow is a real phenomenon likely to exist in the workplace and be a factor in individual satisfaction, growth and performance. Second, there is no agreed upon definition of the flow concept. Third, there is no agreed upon measure of flow and some flow measures [29], are a mixture of antecedents and outcomes of flow. Fourth, individual traits and characteristics, type of jobs, and type of tasks are likely to affect the experience of flow at work.

\section{Flow in nursing}

Nurses occupy a central role in the delivery of health care, though countries may have different health care systems and methods of payment options. Unfortunately, research conducted in various countries has indicated that levels of nurse dissatisfaction, burnout and intent to leave the profession are high [42]. Younger individuals are also less interested in careers in nursing. Some countries are now reporting a shortage of nurses, often compounded by the fact that richer nations are luring nurses away from poorer ones. The health care system has also undergone significant change over the past decade stemming from the greater use of new technologies, offshoring some services to developing countries, advances in medical knowledge, an aging population, more informed and critical users of the health care system, and efforts by governments to further control health care expenditures. Nursing appears to be a crisis.

It is not surprising then, given the central role nurses play in the delivery of health care, that considerable research has been undertaken to understand the work experiences of nurses, particularly as they relate to nurse satisfaction and well-being and patient care. Much of this work has studied "what is wrong" with hospitals and health care more generally and with nursing more specifically. It has concentrated on issues of workload, lack of resources, overtime work, and increases in abuse experienced in the work place by nursing staff as these affect burnout, depression, psychosomatic symptoms, absenteeism and intent to leave the profession [43-46]. The bulk of nursing research has used a stressor-strain framework and has contributed a great deal to our understanding of the experiences of nurses in their workplaces. These are all important subjects but they tell only part of the story.

The present study examines the relationship of flow and nurse work experiences, satisfactions, and psychological well-being. It provides a preliminary examination of the general hypothesis that flow would be associated with more favorable work and well-being outcomes. A study of flow in nursing seemed appropriate given the mission of helping and caring. Turkey, siilar to most other countries, is currently facing a nursing shortage. It also extends the study of flow to Turkey to examine the generalizability of previous North American results. The general hypothesis underlying this study was that nurses scoring higher on flow would indicate more favorable work outcomes and higher levels of psychological well-being. In addition, it adds to the limited but growing interest in flow in the workplace.

\section{Method \\ Procedure}

This study was carried out in research hospitals in Ankara Turkey, research sites being randomly selected from the 15 research hospitals in that city. Ethics approval was obtained from the Research committee at York University. The Health Ministry sent a cover letter to the Chief Physicians of these hospitals requesting their cooperation. Six hundred questionnaires were administered to staff nurses in the hospitals. Measures originally in English were translated into Turkish using the back translation method. Data were collected in March 2009. Two hundred and twenty-four nurses completed the surveys, a $37 \%$ response rate.

\section{Respondents}

Table 1 presents the personal demographic and work situation characteristics of the sample $(n=224)$. There was considerable diversity on each item. The sample ages ranged from under 25 to over 46, with 128 (59\%) being between 26 and 35. Most were married (77\%), had children (70\%), worked full-time (79\%), wanted to work full-time (99\%), were female (88\%), worked between 41-45 hours per week (69\%), had high school or vocational school education (35 $\%)$, did not have supervisory responsibilities (56\%), had not changed units in the past year (74\%), had five years or less of nursing tenure (59\%), five years or less of nursing tenure (58\%), and worked in a variety of nursing units.

\section{Measures}

Personal and work situation characteristics: These were measured by single items (e.g., age, sex, level of education, unit tenure, hospital tenure).

\section{Flow}

Flow is a positive experiential state when an individual is totally connected to the task in a situation where personal skills are equal to the required challenges; flow is the subjective experience 


\begin{tabular}{|c|c|c|c|c|c|}
\hline Age & $\mathbf{N}$ & $\mathbf{v}$ & Sex & $\mathbf{N}$ & $\%$ \\
\hline 25 or less & 18 & 8.4 & Female & 180 & 87.8 \\
\hline $26-30$ & 76 & 35.3 & Male & 25 & 12.2 \\
\hline $31-35$ & 52 & 24.4 & \multicolumn{2}{|l|}{ Marital Status } & \\
\hline $36-45$ & 44 & 21.5 & Married & 168 & 77.4 \\
\hline $41-45$ & 17 & 8.3 & Single & 49 & 22.6 \\
\hline 46 or older & 8 & 3.9 & & & \\
\hline \multicolumn{2}{|l|}{ Parental Status } & & \multicolumn{2}{|c|}{ Number of Children } & \\
\hline Children & 151 & 70.3 & 1 & 70 & 46.4 \\
\hline \multirow[t]{2}{*}{ Childless } & 64 & 29.7 & 2 & 76 & 50.3 \\
\hline & & & 3 or more & 5 & 3.3 \\
\hline \multicolumn{2}{|l|}{ Education } & & \multicolumn{2}{|l|}{ Work status } & \\
\hline High School & 75 & 34.6 & Full-time & 160 & 79.4 \\
\hline Vocational School & 50 & 23.0 & Part-time & 54 & 20.6 \\
\hline Bachelor's degree & 70 & 32.2 & \multicolumn{2}{|c|}{ Supervisory Duties } & \\
\hline Master's degree & 2 & 0.9 & Yes & 69 & 79.4 \\
\hline Faculty & 20 & 9.2 & No & 148 & 68.2 \\
\hline \multicolumn{2}{|l|}{ Hours worked } & & \multicolumn{2}{|l|}{ Preferred Work } & \\
\hline 40 or less & 39 & 19.8 & status & & \\
\hline $41-45$ & 84 & 42.6 & Full-time & 197 & 99.5 \\
\hline $46-50$ & 38 & 18.3 & Part-time & 1 & 0.5 \\
\hline $51-55$ & 9 & 4.6 & \multicolumn{2}{|l|}{ Hospital Tenure } & \\
\hline \multirow[t]{2}{*}{56 or more } & 27 & 13.7 & 5 years or less & 118 & 57.6 \\
\hline & & & $6-10$ years & 49 & 23.9 \\
\hline \multicolumn{3}{|c|}{ Changed Units Past Year } & $11-15$ years & 14 & 6.8 \\
\hline Yes & 53 & 26.0 & $16-20$ years & 15 & 7.3 \\
\hline No & 151 & 74.0 & 21 years or more & 9 & 4.4 \\
\hline \multicolumn{6}{|l|}{ Nursing Tenure } \\
\hline 5 years or less & 119 & 59.1 & & & \\
\hline $6-10$ years & 41 & 20.4 & & & \\
\hline $11-15$ years & 14 & 7.0 & & & \\
\hline $16-20$ years & 18 & 9.0 & & & \\
\hline 21 years or more & 9 & 4.5 & & & \\
\hline
\end{tabular}

of full involvement with one's job and work [10]. In this research, flow was measured by a 36 item instrument developed by Jackson and Marsh [15]. This scale measured nine dimensions: challengeskill balance, action-awareness merging, clear goals, unambiguous feedback and concentration on the task at hand, sense of control, loss of self-consciousness, transformation and autotelic experience. The reliability of the 36 item scale was .91 . Nurses were asked to answer the questions in relation to their experience at work during the past week Items included "I was aware of how well I was performing during the week", "My goals were clearly defined" and I was challenged, but I believed my skills would allow me to meet the challenge."

\section{Work outcomes}

Ten work outcomes were included.

Job satisfaction: Job satisfaction was measured by a five-item scale $(\alpha=.79)$ developed by Quinn and Shepard [47]. One item was, "All in all, how satisfied would you say you are with your job?" Respondents indicated their responses on a four-point Likert scale (1-Very satisfied, $4=$ Not at all satisfied).

Self-rated job performance: Self-rated job performance was measured by two items (alpha $=.68$ ) Nurses indicated their agreement with the following questions on a five-point Likert scale ( 1 =strongly disagree, $3=$ neutral, $5=$ strongly agree): My supervisor(s) is (are) completely satisfied with my performance." And "My last performance appraisal was highly positive."

\section{Absenteeism}

Nurses indicated first how many days they had been absent from work during the past month, and then how many of these days of absenteeism were due to sickness.

Intent to quit: (=.76) was measured by two items used previously by Burke [48]. An item was, "Are you currently looking for a different job in a different organization?”

\section{Work engagemenst}

Three dimensions of work engagement were assessed using scales developed by Schaufeli, Salanova, Gonzalez-Roma and Bakker and Schaufeli and Bakker [49.50]. Respondents indicated their agreement with each item on a five-point Likert scale ( $1=$ strongly disagree, $3=$ neither agree nor disagree, $5=$ strongly agree).

Vigor: Vigor was measured by six items $(\alpha=.82)$. One item was "At my work, I feel bursting with energy."

Dedication: Dedication was measured by five items $(\alpha=.79)$. An item was "I am proud of the work that I do."

Absorption: Absorption was assessed by six items $(\alpha=.85)$. One item was "I am immersed in my work."

\section{Burnout}

Three dimensions of burnout were measured by the Maslach Burnout Inventory [51]. Respondents indicated how often they experienced each item on a seven-point scale $(0=$ never, $3=a$ few times a month, $6=$ every day).

Exhaustion: Exhaustion was measured by a five-item scale $(\alpha=.86)$. A sample item was "I feel burned out from my work."

Cynicism: Cynicism was assessed by a five-item scale $(\alpha=.58)$. One item was "I have become more cynical about whether my work contributes anything."

Efficacy: Efficacy was measured by six items $(\alpha=.77)$. An item was "I have accomplished many worthwhile things in this job."

\section{Psychological well-being}

Five aspects of psychological well-being were included.

Positive Affect: Positive Affect was measured by a ten-item scale $(\alpha=.91)$ developed by Watson, Clark and Tellegen [52]. Respondents indicated how often they experienced these items during the past week (e.g., excited, proud, excited) on a five-point Likert scale ( $1=$ not at all, $5=$ extreme)

Negative affect: Negative affect was also measured by a tenitem scale ( $\alpha=.86)$ developed by Watson, Clark and Tellegen [52]. Respondents indicated how often they experienced these (e.g., irritable, nervous, distressed) on the same frequency scale.

Psychosomatic symptoms: Psychosomatic symptoms was 
measured by nineteen items $(\alpha=.91)$ developed by Quinn and Shepard [47]. Respondents indicated how often they had experienced each physical condition (e.g., headaches, having trouble getting to sleep) during the past year. Responses were made on a seven-point Likert scale ( $1=$ never, $4=$ often $)$.

Medication use: Medication use was measured by a five-item scale $(\alpha=.75)$ developed by Quinn and Shepard [47]. Respondents indicated how often they took listed medications (e.g., pain medication, sleeping pills) on a five point scale $(1=$ never, $5=\mathrm{a}$ lot $)$.

Life satisfaction: Life satisfaction was assessed by a five-point scale $(\alpha=.90)$ developed by Quinn and Shepard [47]. Respondents indicated their agreement with each item (e.g., in most ways my life is close to ideal) on a seven-point Likert agreement scale ( $1=$ strongly agree, $4=$ neither agree not disagree, $7=$ strongly disagree).

\section{Results}

\section{Descriptive information}

The item mean on the flow scale was 4.0, s.d.=.79 $(\mathrm{N}=140)$. Nurses "somewhat agreed with each item. This mean value was significantly higher than that obtained in a study of Norwegian journalist [32].

\section{Hierarchical regression analysis}

Hierarchical regression analyses were undertaken in which various work outcomes, indicators of psychological well-being and perceptions of hospital functioning were regressed on three blocks of predictors entered in a specified order. The first block of predictors $(\mathrm{n}=4)$ consisted of personal demographics (e.g., age, marital status, level of education); the second block $(n=4)$ consisted of work situation characteristics (e.g., job has supervisory duties, hospital tenure, work status, full-time versus part-time); the third block of predictors $(n=1)$ consisted of the flow measure When a block of predictors accounted for a significant amount or increment in explained variance $(p<.05)$, individual variables within these blocks having significant and independent relationships with the criterion variable $(p<.05)$ were identified. These variables are indicated in the tables that follow along with their respective $\mathrm{s}$.

\section{Predictors of flow}

The measure of flow was regressed on two blocks of predictors (personal demographics and work situation characteristics). No block of predictors accounted for a significant amount or increment in explained variance on flow.

\section{Flow and work outcomes}

Table 2 presents the results of hierarchical regression analyses in which nine work outcomes were regressed separately on the three blocks of predictors: personal demographics, work situation characteristics, and flow. The following comments are offered in summary. Flow accounted for a significant increment in explained variance on five of the ten of the work outcomes. Nurses scoring higher on flow indicated higher levels of efficacy, self-rated job performance, vigor, dedication and absorption (Bs=.34, .40, .22, .38 and .38 , respectively).

\section{Flow and posychological well-being}

Table 3 shows the results of hierarchical regression analyses

\begin{tabular}{|c|c|c|c|c|}
\hline \multicolumn{5}{|c|}{ Work Outcomes } \\
\hline Job Satisfaction ( $N=164)$ & $\mathbf{R}$ & $\mathbf{R}^{2}$ & $\Delta \mathbf{R}^{2}$ & $\mathbf{P}$ \\
\hline Personal demographics & .22 & .05 & .04 & NS \\
\hline $\begin{array}{l}\text { Work situationv } \\
\text { Supervisory duties(.20) }\end{array}$ & .33 & .11 & .06 & .05 \\
\hline Flow & 34 & .11 & .00 & NS \\
\hline \multicolumn{5}{|c|}{ Self-rated Job Performance(N=164) } \\
\hline Personal demographics & .11 & .01 & .01 & NS \\
\hline Work situation & .20 & .04 & .03 & NS \\
\hline Flow $(.40)$ & .44 & .19 & .15 & .001 \\
\hline \multicolumn{5}{|l|}{ Days Absent ( $\mathrm{N}=165$ ) } \\
\hline Personal demographics & .09 & .01 & .01 & NS \\
\hline Work situation & .13 & .01 & .01 & NS \\
\hline Flow & 13 & .02 & .00 & NS \\
\hline \multicolumn{5}{|l|}{ Intent to Quit (N=164) } \\
\hline Personal demographics & .36 & .13 & .13 & .001 \\
\hline Marital status $(-.20)$ & & & & \\
\hline Work situation & .42 & .17 & .04 & .01 \\
\hline Flow & .42 & .18 & .01 & NS \\
\hline \multicolumn{5}{|l|}{ Engagement } \\
\hline \multicolumn{5}{|l|}{ Vigor ( $N=167)$} \\
\hline Personal demographics & .26 & .07 & .07 & .05 \\
\hline Work situation & .41 & .17 & .10 & .001 \\
\hline Supervisory duties (.19) & & & & \\
\hline Changed units (.19) & & & & \\
\hline Flow $(.22)$ & .46 & .21 & .04 & .001 \\
\hline \multicolumn{5}{|l|}{ Dedication $(\mathrm{N}=165)$} \\
\hline Personal demographics & .13 & .02 & .02 & NS \\
\hline Work situation & .35 & .12 & .10 & .001 \\
\hline Supervisory duties (.14) & & & & \\
\hline Work status $(.25)$ & & & & \\
\hline Flow $(.38)$ & .50 & .25 & .13 & .001 \\
\hline \multicolumn{5}{|l|}{ Absorption (N=165) } \\
\hline Personal demographics & .15 & .02 & .02 & NS \\
\hline Work situation & .36 & .13 & .11 & .01 \\
\hline Unit tenure $(-.37)$ & & & & \\
\hline Changed units (.15) & & & & \\
\hline Flow (.38) & .45 & .20 & .07 & .001 \\
\hline \multicolumn{5}{|l|}{ Burnout } \\
\hline \multicolumn{5}{|l|}{ Exhaustion $(\mathrm{N}=165)$} \\
\hline Personal demographics & .24 & .06 & .06 & .05 \\
\hline Work situation & 32 & .10 & .04 & .05 \\
\hline Flow & .32 & .10 & .00 & NS \\
\hline \multicolumn{5}{|l|}{ Cynicism (N=166) } \\
\hline Personal demographics & .13 & .02 & .02 & NS \\
\hline Work situation & .26 & .08 & .06 & NS \\
\hline Flow & .28 & .08 & .00 & NS \\
\hline \multicolumn{5}{|l|}{ Efficacy $(\mathrm{N}=166)$} \\
\hline Personal demographics & & & & \\
\hline Work situation & .14 & .02 & .02 & NS \\
\hline Virtues & .29 & .08 & .06 & NS \\
\hline Flow $(.34)$ & 44 & .19 & .11 & 001 \\
\hline
\end{tabular}

involving five indicators of psychological well-being: positive and negative affect, psychosomatic symptoms, and medication use and life satisfaction. The following comments are offered in summary. 
Flow accounted for a significant increment in explained variance in only one analysis: Positive affect). Nurses reporting higher levels of flow also indicated more positive affect $(\mathrm{B}=.28)$.

It is possible to draw some tentative conclusions across all the analyses that were undertaken. First, personal demographics almost never accounted for a significant amount of explained variance in any of the analyses. Second, work situation characteristics accounted for a significant increment in explained variance in about half the hierarchical regressions; more significant relationships were observed with indicators of work outcomes than with the other types of outcomes. Third, flow accounted for a significant increment in explained variance in about half of the analyses, primarily on work outcomes.

\section{Discussion}

This exploratory study provided partial support for the general hypothesis underlying the research. That is, nurses reporting higher levels of flow performed at a higher level (greater efficacy) and were more engaged at work (Table 2). These results were supportive of previous theorizing [8,53-55] and consistent with empirical findings $[29,56,57]$. Thus flow seems to be associated with greater satisfaction and involvement at work. Our findings, however, showed on a weak relationship of flow with indicators of psychological well-being, not support previous results. It is not clear why flow failed to predict psychological well-being in this sample.

\section{Why is flow associated with positive outcomes?}

Four different explanations for the association of flow with higher levels of individual and organizational well-being have been proposed. First, flow, as reported above, was associated with positive emotions. In addition, flow tended to be associated with other virtues, increasing the experiencing of positive emotions even more [58]. Individuals experiencing positive emotions are more likely

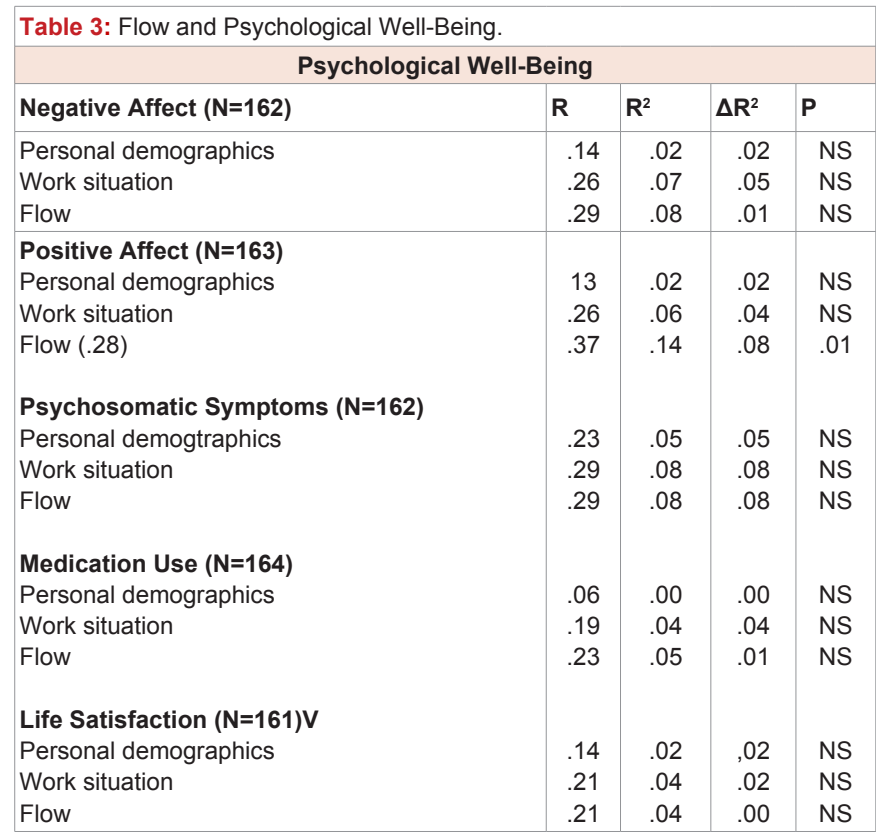

to be proactive, to engage in organizational citizenship behaviors, be outgoing, and think and act in more creative ways. Fredrickson $[59,60]$, developed her "broaden and build" theory of positive emotions, which, at its core, suggests that positive emotions foster an upward spiral of individual functioning [61].

Second, flow is associated with higher levels of individual psychological and physical health. Healthy individuals are likely to being heightened focus, vigor and persistence, which in turn contribute to higher levels of individual and organizational functioning [62-64].

Third, flow is associated with increases in both personal and job or organizational resources over time. This would be predicted by Fredrickson's "broaden and build" theory; the rich keep getting richer. Particular virtues are likely to increase over time, and the consequences of these virtues (e.g., proactive behavior, creativity, vigor) are also likely to increase over time resulting in more personal resources. In addition, virtues would also be associated with more job and organizational resources over time as well (e.g., more variety, more feedback and learning). Virtues can make it easier for individuals to bounce back after setbacks in their personal or work lives $[65,66]$.

Fourth, flow has also been found to influence colleagues in the workplace; virtues can be transferred to others. To the extent to which this occurs, the unit or organization becomes stronger and more effective. Positive emotions can be transferred to colleagues and customers $[29,67,68]$.

\section{Developing flow in the workplace}

Csikszetmihalyi [12], believes that flow can be created in organizations. These include addressing the eight contributors of the flow experiences. Organizations need to undertake the following: clarify their goals, determine performance goals, make feedback available, help employees acquire the skills needed to do their jobs, allow employees some freedom and control, make it possible for employees to concentrate on their jobs, and allow employees some control over time. In addition, Hooker and Csikszentmihalyi [69], discuss the importance of sharing leadership in creating flow experiences and Heckman [70], adcovates the use of teams to support flow.

There have been some efforts to develop other individual virtues that appear to have been successful. Emmons and McCullough [71], in studies of university students, developed gratitude by having them "count their blessings," or to write down up to five things in their lives over the past week that they were grateful or thankful for. Bakker [72], describes his work with individuals and organizations to increase engagement using both interviews and survey data. Seligman [73,74], lays out his program for increasing optimism and happiness. Brown and Ryan [75] show how their efforts to develop mindfulness among cancer patients resulted in both increased mindfulness over time and declines in mood disturbances and stress. Eisen Berger [76], suggests how learned industriousness can be increased. Snyder [77,78], illustrates ways in which hope can be heightened. Finally, Luthans and his colleagues $[53,56,79]$, describe a micro-intervention in some detail that they have used to increase levels of Psychological Capital (hope, optimism, resilience). These efforts provide a solid basis for further efforts to increase virtues, and outcomes such as flow. 


\section{High performing hospitals}

Although the concept of flow may not have been introduced, several studies of high performing hospitals, termed magnet hospitals because these hospitals attract and retain nursing staff and provide high levels of patient care, have been reported [80-84]. These hospitals are characterized by a philosophy of caring from the top management that permeates the patient care environment, leaders that are visible and approachable, facilities that support high quality care for patients, high levels of information being passed around the nursing units, good working relationships between doctors and nurses, nurse participation in health care and hospital decision making, reasonable and fair levels of pay, an emphasis on nurse training and continuing education, and possibilities for career advancement [85].

\section{Limitations of the research}

Some limitations of the research should be noted to put the findings into a broader context. First, the sample of nurses in this exploratory study was relatively small $(n=224)$ and was relatively young, inexperienced and had low levels of nursing education compared to North American and European samples. Second, it was not possible to determine the representativeness of those nurses that participated. Third, all data were collected using self-report questionnaires raising the possibility of response set tendencies. Fourth, data were collected at one point in time making it difficult to determine causality. Fifth, a few of the measures had levels of internal consistency reliability below the generally accepted standard of .70. Sixth, all respondents worked in research hospitals It is not clear the extent to which our results would generalize to other samples of nurses working in other hospitals.

\section{Future research directions}

Future research needs to involve a larger and representative sample of nurses drawn from several different hospitals. In addition, to flow, the inclusion of other virtues such as hope, self-esteem, gratitude and would add to our understating of the relationship of various virtues with individual and organizational flourishing [86,87]. Future research should incorporate longitudinal designs to permit examination of causal directions and reciprocal relationships. Incorporating measures of flow at individual, unit and hospital levels would illuminate the link between various levels of analysis. Finally, efforts to increase the levels of flow at individual and unit levels appear to be a promising and necessary endeavor as well.

\section{Footnotes}

Preparation of this manuscript was supported part by York University and Nevsehir University. We than the Health Ministry for their support, the hospitals for their cooperation, and our respondents for their participation.

\section{References}

1. Bakker AB, Schaufeli WB, Leiter MP, Taris TW (2008) Work engagement: An emerging concept in occupational health psychology. Work and Stress 22: 187-200.

2. Myers DG (2000) The funds, friends and faith of happy people. American Psychologist 55: 56-67.
3. Peterson CM, Seligman MFP (2003) Positive organizational studies: Lessons from positive psychology. In K. S. Cameron, J. E. Dutton \& R. E. Quinn (eds.) Positive organizational scholarship. San Francisco: Berrett-Koehler 14-28.

4. Cameron KS (2003) Organizational virtuousness and performance. In K. S. Cameron, J. E. Dutton \& R, E. Quinn (eds.) Positive organizational scholarship.p San Francisco: Berrett-Koehler 48-65.

5. Fredrickson BL (1998) What good are positive emotions? Review of General Psychology 2: 300-319.

6. Fredrickson BL (2003a) The value of positive emotions. American Scientist 91: 330-335.

7. Seligman MEP, Csikszentmihalyi M (2000) Positive psychology: An introduction. American Psychologist 55: 5-14.

8. Cameron KS, Dutton JE, Quinn RE (2003) Positive organizational scholarship. San Francisco: Berrett-Koehler.

9. Luthans F (2002) Positive organizational behavior: Developing and managing psychological strengths. Academy of Management Executive 16: 57-72I.

10. Csikszentmihalyi M (1990) Flow: The psychology of optimum experience. New York: Harper Collins.

11. Csikszentmihalyi M (1997) Finding flow. New York: Basic books.

12. Csikszentmihalyi M (2003) Good business. New York: Viking.

13. Jackson SA (1996) Toward a conceptual understanding of the flow experience in elite athletes. Research Quarterly for Exercise and Sport 67: 76-90.

14. Jackson SA, Kimiecik JC, Ford SK, Marsh HW (1998) Psychological correlates of flow in sport. Journal of Sport and Exercise Psychology 20: 358378.

15. Jackson SA, Marsh HW (1996) Development and validation of a scale to measure optimal experience: The Flow State Scale Journal of Sport and Exercise Psychology 18: 17-35.

16. Jackson SA, Thomas PR, Marsh HW, Smethurst CJ (2001) Relationships between flow, self-concept, psychological skills, and performance. Journal of Applied Sport Psychology 13: 129-153.

17. Jackson SA (1992) Athletes in flow: A qualitative investigation of Flow states in elite figure skaters. Journal of Applied sport Psychology 4: 161-180.

18. Jackson SA, Csikszentmihalyi M (1999) Flow in sports: The keys to optimal experiences and performance. Champaign, IL: Human Kinetics.

19. Murcia JAM, Gimeno EC, Coll DGC (2008) Relationships among goal orientations, motivational climate and flow in adolescent athletes: Differences by gender. The Spanish Journal of Psychology 11: 181-191.

20. Mills AS (2005) Flow experiences among Appalachian Trail thru-hikers. Proceedings of the 2005 Northeastern Recreation Research Symposium 366-370.

21. Vlachooulos SP, Karageorghis Cl, Terry PC (2000) Hierarchical confirmatory factor analysis of the Flow State Scale in exercise. Journal of Sports Sciences 18: 815-823.

22. Martin JJ, Cutler K (2002) An exploratory study of flow and motivation in theater actors. Journal of Applied Sport Psychology 14: 344-352.

23. Bakker AB (2005) Flow among music teachers and their students: The crossover of peak experiences. Journal of Vocational Behavior 66: 26-44.

24. McDonald R, Byrne C, Carlton L (2006) Creativity and flow in musical composition: An empirical investigation. Psychology of Music 34: 292-306.

25. O'Neil, S. (1999) Flow theory and the development of musical performance skills. Bulletin of the council for Research in Music Education, 141, 129-134.

26. Ghani JA, Deshpande SP (1994) Task characteristics and the experience of optimal flow in human-computer interaction. Journal of Psychology 128: 381391.

27. Trevino LK, Webster J (1992) Flow in computer-mediated communication. Communication Research 19: 539-573. 
28. Webster J, Trevino LK, Ryan L (1993) The dimensionality and correlates of flow in human computer interactions. Computers in Human Behavior 9: 411 425

29. Bakker AB (2008) The work-related flow inventory: Construction and initial validation of the WOL.F Journal of Vocational Behavior 72: 400-414.

30. Demerouti E (2006) Job characteristics, flow, and performance: The moderating role of conscientiousness. Journal of Occupational Health Psychology 11: 266-280.

31. Quinn RW (2005) Flow in knowledge work: High performance experience in the design of national security technology. Administrative Science Quarterly 50: $610-641$

32. Burke RJ, Matthiesen SB (2004) Correlates of flow at work among Norwegian journalists. Journal of Transnational Management 10: 49-58.

33. Clarke SG, Haworth JT (1994) "Flow" experience in the daily lives of sixth form college students. British Journal of Psychology 8: 511-523.

34. Jackson SA, Roberts GC (1992) Positive performance states of athletes: Toward a conceptual understanding of peak performance. The Sport Psychologist 6: 156-171.

35. Salanova M, Bakker AB, Llorens S (2006) Flow at work: Evidence for an upward spiral of personal and organizational resources. Journal of Happiness Studies 7: 1-22.

36. Fritz BS, Avsec A (2007he experience of flow and subjective well-being of music students. Horizons of Psychology 16: 5-17.

37. Eisenberger R, Jones JR, Stinglhamber F, Shanock L, Randall AT (2005) Flow experiences at work: For high need achievers only? Journal of Organizational Behavior 26: 755-775.

38. Csikszentmihalyi M, Csikszentmihalyi I (1988) Optimal experience: Psychological studies of flow in consciousness. Cambridge: Cambridge University Press.

39. Csikszentmihaly M, LeFevre J (1989) Optimal experience $n$ work and leisure. Journal of Personality and Social Psychology 56: 815-822.

40. Privette G (1983) Peak experience, peak performance, and flow: A comparative analysis of positive human experiences. Journal of Personality and Social Psychology 45: 1361-1368.

41. Privette G, Bundrick CM (1991) Peak experience, peak performance, and flow. Journal of social Behavior and Personality 6: 169-188.

42. Aiken LH, Clarke SP, Sloane DM, Sochalski JA, Busse R,et al. (2001) Nurses' reports on hospital care in five countries. Health Affairs 20: 343-353.

43. Aiken LH, Clarke SP, Sloane DM, Sochalski J, Silber JH (2002) Hospital nurse staffing and patient mortality, nurse burnout and job dissatisfaction. Journal of the American Medical Association 288: 1987-1993.

44. Burke RJ (2003) Length of shift, work outcomes, and psychological wellbeing of ursing staff. International Journal of Public Administration 26: 1637 1646.

45. Vahey DC, Aiken LH, Sloane DM, Clarke SP, Vargas D (2004) Nurse burnout and patient satisfaction. Medical Care 42: 1157-1166.

46. Payne N (2001) Occupational stressors and coping as determinants of burnout in female hospice nurses. Journal of Advanced Nursing 33: 396-406.

47. Quinn RP, Shepard LJ (1974) The 1972-73 Quality of Employment Survey. Ann Arbor, MI: Institute for Social Research, University of Michigan.

48. Burke RJ (1991) Early work and career experiences of female and male managers: Reasons for optimism? Canadian Journal of Administrative Sciences 8: 224-230.

49. Schaufeli WB, Salanova M, Gonzalez-Roma V, Bakker AB (2002) The measurement of engagement and burnout: A confirmative analytic approach. Journal of Happiness Studies 3: 71-92.

50. Schaufeli WB, Bakker AB (2004) Job demands, job resources and thei relationship with burnout and engagement: A multi-sample study. Journal of Organizational Behavior 25: 293-315.

51. Maslach C, Jackson SE, Leiter MP, Schaufeli WB, Schwab RL (1996) The Maslach Burnout Inventory ( $3^{\text {rd }}$ ed.).Palo Alto, CA: Consulting Psychologists Press.

52. Watson D, Clark LA, Tellegen A (1988) Development and validation of brief measures of positive and negative affect: The PANAS scales. Journal of Personality and Social Psychology 54: 1063-1070.

53. Luthans F, Youssef CM, Avolio BJ (2007) Psychological capital. New York: Oxford University Press.

54. Nelson DL, Cooper CL (2007) Positive organizational behavior: Accentuating the positive at work. Thousand Oaks, CA: Sage Publications.

55. Snyder CR, Lopez S (2002) Handbook of positive psychology. Oxford: Oxford University Press.

56. Luthans F, Vogelgesang GF, Lester PB (2006) Developing the psychological capital of resiliency. Human Resources Development Review 5: 25-44.

57. Luthans F, Avolio BJ, Avey JB, Norman SM (2007) Positive psychological capital: Measurement and relationship with performance and satisfaction. Personnel Psychology 60: 541-572.

58. Carver CS (1998) Resilience and thriving: Issues, models and linkages. Journal of Social Issues 54: 245-266.

59. Fredrickson BL (2001) The role of positive emotions in positive psychology: The broaden-and-build theory of positive emotions. American Psychologist 56: 218-226.

60. Fredrickson BL (2003) Positive emotions and upward spirals in organizations In K. Cameron, J. Dutton \& R. E. Quinn (eds.) Positive organizational scholarship. San Francisco: Berrett-Koehler 163-175.

61. Fredrickson BL, Branigan CA (2005) Positive emotions broaden the scope of attention and thought-action repertoires. Cognition and Emotion 19: 313-332.

62. Fredrickson BL, Joiner $\mathrm{T}$ (2002) Positive emotions trigger upward spirals toward emotional well-being. Psychological Science 13: 172-175.

63. Ryan RM, Frederick C (1997) On energy, personality, and health: Subjective vitality as a dynamic reflection of well-being. Journal of Personality 65: 529565.

64. Shirom A (2003) Feeling vigorous at work? The construct of vigor and the study of positive affect in organizations. In D. Ganster \& P. L. Perrewe (eds.) Research in organizational stress and well-being. Greenwich CT: JAI Press. 1: 3: 135-164.

65. Tugade MM, Fredrickson BL (2004) Resilient individuals can use positive emotions to bounce back from negative emotional experiences. Journal of Personality and Social Psychology 86: 320-333.

66. Youssef CM, Luthans F (2007) Positive organizational behavior in the workplace: The impact of hope, optimism, and resilience. Journal of Management 33: 774-800.

67. Baker W, Cross R, Wooten M (2003) Positive organizational network analysis and energizing relationships. In K. S.. Cameron, J. E..Dutton, \& R. E. Quinn (eds.) Positive organizational scholarship San Francisco: Berrett-Koehler 328-342.

68. Fredrickson BL, Losada MF (2005) Positive affect and the complex dynamics of human flourishing. American Psychologist 60: 678-686.

69. Hooker C, Csikszentmihaly M (2003) Flow, creativity and shared leadership. In C. L. Pearce \& J. A. Conger (eds.) Shared leadership: Reframing the hows and whys of leadership. Thousand Oaks, CA: Sage 217-234.

70. Heckman F (1997) Designing organizations for flow experiences. Journal of Quality and Participation 20: 24-33.

71. Emmons RA, McCullough ME (2003) Counting blessings versus burdens: An experimental investigation of gratitude and subjective well-being in daily life. Journal of Personality and Social Psychology 84: 377-389. 
72. Bakker $A B$ (2009). Building engagement in the workplace. In R. J. Burke \& C. L. Cooper (eds.) The peak performing organization. London: Routledge 01-44.

73. Seligman MEP (1998) Learned optimism. New York: Pocket Books.

74. Seligman MEP (2002) Authentic happiness. New York: Free Press.

75. Brown KW, Ryan RM (2001) The benefits of being present: Mindfulness and its role in psychological well-being. Journal of Personality and Socia Psychology 84: 822-848.

76. Eisenberger R (1992) Learned industriousness. Psychological Review 99 248-267

77. Snyder CR (1994) The psychology of hope: You can get there from here. New York: Free Press 423-436.

78. Snyder CR (1995) Conceptualizing, measuring, and nurturing hope. Journa of Counseling and Development 73: 355-360.

79. Luthans F, Avery JB, Avolio BJ, Norman SM, Combs GM, et al. (2006) Psychological capital development: Towards a micro-intervention. Journal of Organizational Behavior 27: 387-393.

80. Aiken LH, Smith HL, Lake ET (1994) Lower medicare mortality among a set of hospitals known for good nursing care. Medical Care 32: 771-787.

81. Havens DS, Aiken LH (1999) Shaping systems to promote desire outcomes: The magnet hospital model. Journal of Nursing Administration 29: 14-20.
82. Kramer M (1990) The magnet hospitals: Excellence revisited. Journal of Nursing Administration 20: 25-30.

83. Kramer M, Schmalenberg C (1998a) Magnet hospitals. Part I. Institutions of excellence. Journal of Nursing Administration 18: 13-24.

84. Kramer M, Schmalenberg C (1998b) Magnet hospitals. Part II. Institutions of excellence. Journal of Nursing Administration 18: 11-29.

85. Parker ME (1993) Patterns of nursing theories in practice. New York:National League for Nursing Press. Parker, S. K. (1998). Enhancing role breadth selfefficacy: The roles of job enrichment and other organizational interventions. Journal of Applied Psychology 83: 835-852.

86. Emmons RA (2003) Acts of gratitude in organizations. In KS, Cameron, J. E. Dutton \& R.E.

87. Emmons RA, Crumpler CA (2000) Gratitude as a human strength: Appraising the evidence. Journal of Social and Clinical Psychology 19: 56-69.

88. Quinn (eds.) Positive organizational scholarship. San Francisco: BerrettKoehler. pp. 81-93.

89. Nakamura J, Csikszentmihalyi M (2002) The concept of flow. In S. J. Lopez \& C. R. Snyder (eds.) Handbook of positive psychology. London: Oxford University Press 239-263.

90. Park N, Peterson CM (2003) Virtues and organizations. In K. S. Cameron, J. E. Dutton \& R. E. Quinn (eds.) Positive organizational scholarship. San Francisco: Berrett-Koehler 33-47.

Copyright: (C) 2016 Burke RJ, et al. This is an open-access article distributed under the terms of the Creative Commons Attribution License, which permits unrestricted use, distribution, and reproduction in any medium, provided the original author and source are credited. 